\title{
РЕКОНСТРУКЦИЯ НЕФТЯНЫХ ШАХТ № 1, 2 И 3. ВЗАИМОСВЯЗЬ СМЕРТЕЛЬНЫХ СЛУЧАЕВ НА ПРОИЗВОДСТВЕ И КАЧЕСТВА ВЫПОЛНЕНИЯ ПРОЕКТНОЙ ДОКУМЕНТАЦИИ. АНАЛИЗ ОШИБОК
}

\author{
Д.Ю. Седнев \\ Горный институт УрО РАН, г. Пермь
}

\begin{abstract}
Аннотация. Главными задачами проектирования горнодобывающих предприятий являются обеспечение технологических показателей задания на проектирование и выполнение требований стандартов, норм и правил законодательной базы Российской Федерации в области промышленной безопасности. При проектировании и дальнейшем авторском сопровождении проектов подземных комплексов нефтяных шахт важным аспектом является оценка инцидентов и аварий с позиции соответствия проектной документации фактическому состоянию подземного горнодобывающего комплекса. В статье проведен краткий анализ аварий, произошедших на нефтяных шахтах в последние годы, и даны предложения по предупреждению их в будущем с точки зрения разработчика проектной документации.
\end{abstract}

Ключевые слова: нефтяная шахта, рудничный пожар, авария, инцидент, обоснование безопасности, федеральные нормы и правила.

\section{Введение}

ГИ УрО РАН в период с 2018 по 2020 гг. подготовил проектную документацию по реконструкции подземных комплексов нефтяных шахт НШ-1, -2, и -3 НШПП «Яреганефть» ООО «ЛУКОЙЛ-Коми». Номера положительных заключений в системе единого государственного реестра заключений (ЕГР3): 11-1-1-3-0351932020, 11-1-1-3-034549-2020 и 11-1-1-3-035764-2019. Разработка проектов нефтяных шахт осуществлялась на базе технического проекта, в котором была использована система разработки, автором которой является Ю.П. Коноплёв, заложивший основы норм промышленной безопасности при термошахтной системе разработки [1].

Целью проектов реконструкции являлось увеличение уровня добычи нефти, отработка оставшихся запасов и приведение шахт к действующим нормам промышленной безопасности. На момент написания статьи основная нормативная база нефтяных шахт в связи с их уникальностью - одновременное ведение и нефтедобычных, и горных работ - состоит из двух актуализированных федеральных норм и правил, а именно:

1. Приказ Ростехнадзора от 15.12.2020 N 534 «Об утверждении федеральных норм и правил в области промышленной безопасности "Правила безопасности в нефтяной и газовой промышленности"» [2].

2. Приказ Ростехнадзора от 08.12.2020 N 505 «Об утверждении Федеральных норм и правил в области промышленной безопасности "Правила безопасности при ведении горных работ и переработке твердых полезных ископаемых"» [3].

Современные нормативные документы не всегда учитывают болезненный опыт эксплуатации нефтяных шахт, поскольку действующей научно-проектной школы, постоянно взаимодействующей с государственными органами при формировании проектных решений, до настоящего времени не существовало.

В период с 2013 по 2021 гг. на НШПП «Яреганефть» были зафиксированы следующие аварии, повлекшие за собой смертельные случаи: 
1. Смертельный случай в подъемном комплексе ствола Лыа-Йоль шахты НШ-2 в 2015 году (аналогичный случай был в 2005).

2. Прорыв пара в выработки 325 п. ш. шахты НШ-2 (2 погибших) (2015 год).

3. Пожар в уклонном блоке 1-3Д Север шахты НШ-1 в 2019 году (2 погибших).

4. Пожар в уклонном блоке 3Т-4 НШ-3 в 2020 году (2 погибших).

5. Пожар в электровозном депо НШ-1 (без смертельных случаев, работа предприятия была парализована в течение полугода).

Смертельные случаи на горнодобывающих предприятиях расследуются в соответствии с Приказом Ростехнадзора от 08.12.2020 N 503 «Об утверждении Порядка проведения технического расследования причин аварий, инцидентов и случаев утраты взрывчатых материалов промышленного назначения» [4]. Одними из задач проектных организаций являются сопровождение таких расследований и оценка нарушений норм промышленной безопасности, имевших место при авариях. Непосредственной вины проектировщиков нефтяных шахт, повлекших смертельные случаи на нефтяных шахтах, нет, однако важнейшей задачей проектных организаций, выполняющих проектные работы на опасных производственных объектах горной отрасли, является заблаговременное предупреждение аварий и инцидентов с помощью разработки таких проектных решений, которые были бы направлены на недопущение и ликвидацию возможных негативных событий еще на начальной стадии.

\section{Анализ смертельных случаев и предложения со стороны проектировщиков}

Смертельный случай на вентиляционном стволе Лыа-Йоль шахты НШ-2 произошел по вине машинистки подъемной машины и из-за общего состояния подтопленного вентиляционного ствола. В данном случае работы по ремонту выполнялись без проектной и рабочей документации, что не позволило спроектировать блокировки работы подъемной машины в период проведения ремонтных работ.

Прорыв пара (и последовавшее за ним повышение температуры в горных выработках) с последующим групповым смертельным случаем в значительной степени предупреждался бы проектным решением по мониторингу температуры в горных выработках с помощью оптического кабеля и автоматической блокировки паропроводов в случае увеличения температуры в конкретном месте вдоль трассы паропровода. На рисунке 1 приведена принципиальная схема организации мониторинга температуры.

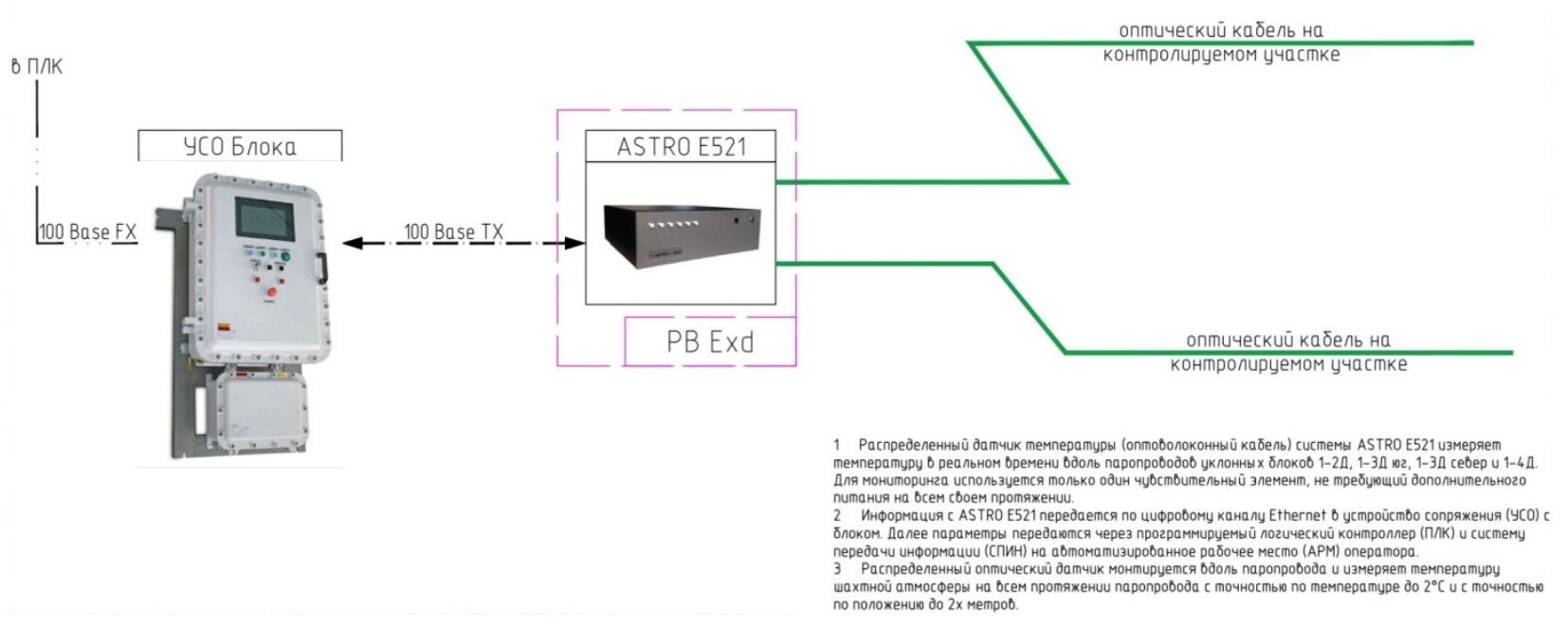

Рис. 1. Принципиальная схема мониторинга температуры паропровода 
Пожар в электровозном депо произошел по причине курения в горных выработках, при этом с точки зрения проектирования причины пожара кроются в отсутствии в депо системы автоматического пожаротушения. Крепь горных выработок депо была частично костровой с горючей затяжкой, но, согласно требованиям норм, выработки с электрооборудованием должны закрепляться негорючей крепью. Таким образом, сочетание негорючей, чистой, без подтеков крепи в совокупности с автоматической системой тушения даже при курении смогли бы остановить пожар в начальной стадии.

Пожары в уклонных блоках 3Т-4 и 1-3Д Север имеют идентичные последствия, но разные причины появления. В первом случае были нарушены требования по монтажу оборудования пускателей, а также осуществлялось курение в горных выработках нефтяного пласта; во втором случае были нарушены требования по сопровождению огневых работ силами ВГСЧ. Уклонные блоки нефтяных шахт являются максимально пожароопасными объектами: проектной документацией огневые работы предусматриваются только в случае монтажа труб и трубопроводов в вертикальных скважинах, входящих в горные выработки. В уклонном блоке 3Т-4 огневые работы проектом не предусматривались. Примечательно то, что через вентиляционную скважину секционного проветривания (предусмотренную проектом) уклонного блока 1-3Д Север был спасен человек, при этом данный вариант спасения не был предусмотрен планом ликвидации аварий. План горных выработок приведен на рисунке 2.

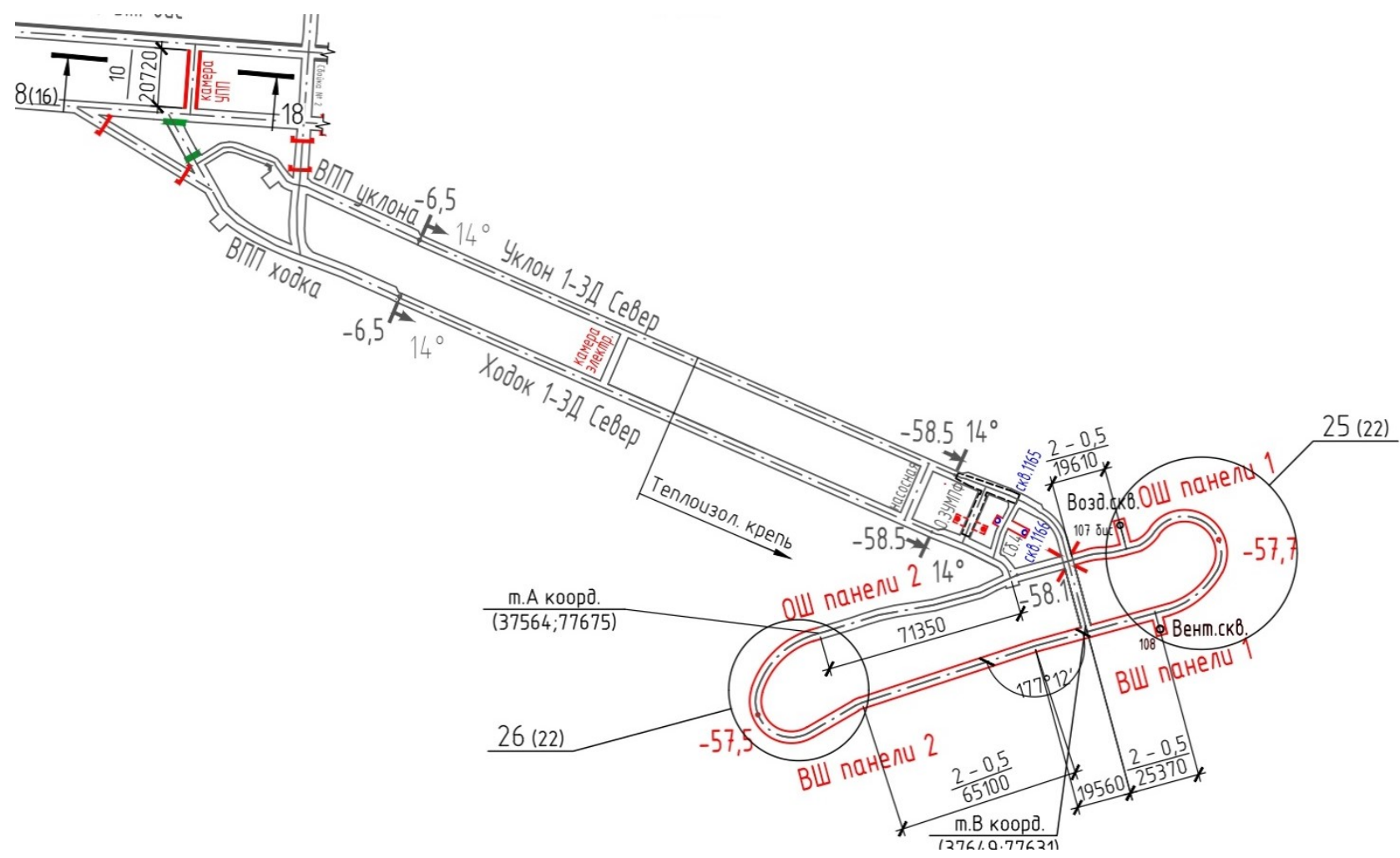

Рис. 2. Схема расположения горных выработок уклонного блока 1-3Д Север

При эксплуатации уклонных блоков 3Т-4 и 1-3Д Север были допущены следующие нарушения: размещение электрооборудования в выработках с горючей крепью и на основной струе, отсутствие негорючей теплоизоляции. Впрочем, выполнение данных требований не является гарантом исключения подобных аварий в будущем. В связи с многочисленными пожарами, произошедшими на ярегских 
нефтяных шахтах, возникает задача повышения пожарной безопасности. Законным механизмом повышения пожарной безопасности является разработка обоснований безопасности с дополнительными требованиями пожарной безопасности, направленными на исключение рисков повторения данных аварий со смертельными случаями [5].

\title{
Заключение
}

Каждое горное предприятие, имеющее многолетний опыт эксплуатации, должно развиваться с учетом минимизации рисков возникновения инцидентов и аварий. Тщательный анализ произошедших аварий, проводимый проектными проектными организациями, и дальнейшая модернизация шахт, направленная на повышение промышленной безопасности, позволит сохранить человеческие жизни.

\section{БИБЛИОГРАФИЧЕСКИЙ СПИСОК}

1. Коноплев Ю.П., Буслаев В.Ф., Ягубов 3.Х., Цхадая Н.Д. Термошахтная разработка нефтяных месторождений. - М.: Недра, 2006. - 288 с.: ил.

2. Федеральные нормы и правила в области промышленной безопасности «Правила безопасности в нефтяной и газовой промышленности»: утв. 15.12.2020, № 534). - Текст электронный // Консорциум КОДЕКС. Электронный фонд правовой и нормативно-технической документации: офиц. сайт. URL: http://docs.cntd.ru/ document/573230594?marker=6520IM (Дата обращения: 20.10.2020).

3. Федеральные нормы и правила в области промышленной безопасности «Правила безопасности при ведении горных работ и переработке твердых полезных ископаемых»: утв. 08.12.2020, № 505. Текст электронный // Консорциум КОДЕКС. Электронный фонд правовой и нормативнотехнической документации: офиц. сайт. - URL: https://docs.cntd.ru/document/573156117. (Дата обращения 20.03.2021).

4. Порядок проведения технического расследования причин аварий, инцидентов и случаев утраты взрывчатых материалов промышленного назначения»: утв. приказом Фед. службы по экологич., технологич. и атомному надзору от 08.12.2020, № 503. - Текст электронный // Консорциум КОДЕКС. Электронный фонд правовой и нормативно-технической документации: офиц. сайт. - URL: https://docs.cntd.ru/document/573191697. (Дата обращения 20.03.2021).

5. Федеральные нормы и правила в области промышленной безопасности «Общие требования к обоснованию безопасности опасного производственного объекта». Вып. 73: утв. 15.07.2013, № 306. - М.: ЗАО НТЦ ПБ, 2013. - 13 с. - (Документы межотраслевого применения по вопросам промышленной безопасности и охраны недр: сер. 03).

\section{НАПРАВЛЕНИЯ СОВЕРШЕНСТВОВАНИЯ МЕТОДОВ СТАТИЧЕСКОГО РАСЧЕТА ЛЕДОПОРОДНЫХ ОГРАЖДЕНИЙ ШАХТНЫХ СТВОЛОВ}

\author{
М.А. Семин \\ Горный институт УрО РАН, г. Пермь
}

\begin{abstract}
Аннотация: В статье проведен анализ возможных погрешностей аналитических формул для расчета внешней нагрузки на ледопородное ограждение и его толщины, способной выдержать расчетную нагрузку. На основании выявленных погрешностей предложены направления совершенствования методов статического расчета ледопородных ограждений шахтных стволов. Выделены физические процессы и факторы, существенным образом влияющие на напряженно-деформированное состояния замороженного породного массива и неучтенные ранее в существующих методах расчета толщины ледопородного ограждения.

Ключевые слова: ледопородное ограждение, статический расчет, напряженно-деформированное состояние.
\end{abstract}

